\title{
ECONOMIC DEVELOPMENT: PROSPECTS FOR GROWTH AND TODAY'S REALITIES
}

\author{
Oksana Yoltukhovska' ${ }^{1}$, Yulia Grudtsyna ${ }^{2}$, Oleksandr Chumak ${ }^{3}$
}

\begin{abstract}
The aim of the article is to analyse the current state of the economy, to review positive and negative trends for further economic growth, and to determine an effective strategy for the development of the economy on this basis. The subject of the study is economic development, prospects for development and the realities of the present. Methodology. The analysis of scientific literature enables to analyse the current economic status and to determine strategic priorities and goals of economic development; in addition, the dialectical method, scientific abstraction, methods of system analysis are used. The results of the study reveal that the implementation of foreign experience during the development of the national economy enables to solve a number of key economic problems that hinder the development of the national economy. The main positive stages of economic development over the last five years are outlined. The study states that an increase in the share of high-tech and innovation sector requires a complex structural transformation of the economy at present. Practical implications. Moreover, the status and determining trends of economic development, considering threats and risks associated with crisis processes in the modern world, are analysed. The main principles of the formation and implementation of the economic development strategy based on the coordination of strategic priorities and strategic objectives of the EU, as well as the need to reform the economic sector to improve promising spheres of the economy, are determined. Relevance/ originality. The study reveals the state of affairs in the economic system, as well as promising trends of the economy, are identified and further developed.
\end{abstract}

Key words: economy, economic development, innovation development, European integration, foreign experience.

JEL Classification: F63, 031

\section{Introduction}

Due to social changes, both positive and individual negative trends occur which to a large extent obstruct the development of Ukraine's statehood. A serious concern is the problem of economic stability (Mohilevskyi, Sevruk, Pavlenko, 2017). In modern realities, Ukraine's economy faces challenges, such as the ATO, uncertainty in the system of political processes, the economic crisis and other factors, which are obstacles to its development. Accordingly, problems that hinder national economic development should be solved (Melnykova et al. 2011). Therefore, the radical socioeconomic transformations over the last decade have caused both positive and negative changes in modern Ukrainian society (Pavlenko, Sevruk, Kobko, 2017). Therefore, nowadays, Ukraine has declared European integration as a key priority of economic policy. The integration strategy of Ukraine should be developed due to our state intention to meet the requirements of the modern world economic system, it is a way of modernizing the economy, overcoming technological

\footnotetext{
Corresponding author:

${ }^{1}$ Uzhhorod National University, Ukraine.

${ }^{2}$ V.I. Vernadsky Taurida National University, Ukraine.

${ }^{3}$ Flight Academy of the National Aviation University, Ukraine.

E-mail:chumak@ukr.net
}

backwardness, attracting foreign investments and new technologies, creating jobs, increasing the competitiveness of domestic producers, entering the world markets (Bahaterenko, 2013).

During the 28 years of Ukraine's independence, many reforms, in most cases ineffective and unproductive, have been carried out. Therefore, in view of the current state of affairs, clearer and more diplomatic approach to the issue of the country's economic growth is required, considering past inaccuracies, as well as innovation and Ukraine's economic potential introduction, should be further developed in view of foreign experience to stabilize the economy.

\section{Literature review}

The theoretical and practical aspects of contemporary economic development of Ukraine are studied in the works of scientists such as O. A. Bahaterenko, N. H. Bazavluk, M. I. Zvieriakov, H. Kalachova, O. S. Kvasha, Ye. V. Kobko, I. V. Lutsykiv, A. Mazaraki, 
T. Melnyk, V. I. Melnykova, S. O. Pavlenko, V. V. Ruden, A. V. Syniakov, V. H. Sevruk, A. V. Todoshchuk, O. V. Shkurupii, O. Yunin. The aim of the article is to analyse the current state of the economy of Ukraine, to review positive and negative trends for further economic growth, and to determine an effective strategy for the development of the Ukrainian economy on this basis.

\section{Presentation of the main material}

The Ukrainian economic status, transformations and processes in the past, and especially in recent years, testify convincingly that the solution of socio-economic development problems has become strategic and global, as well as one of the most important in the state. To overcome crisis phenomena, to respond to global financial crisis consequences, to transfer to sustainable economic growth require the further elaboration of the economic regulation mechanisms both at the state and at the regional level (Ruden).

Accordingly, the development of the world economy up to 2020 will be noticeable due to a number of factors and megatrends, which will lead to significant changes in the overall picture of the world economy and the modification of its organizational forms. Considering the place of Ukraine on the brink of Western European and Eastern European Christian civilization, the formation of a new global architecture makes Ukraine face serious geopolitical, geostrategic, and geo-economic challenges, which it should respond up to 2020 .

At the present formation stage of Ukraine as a European state, a set of strategic measures aimed at economic development in the context of European integration is being implemented (Yunin, Sevruk, Pavlenko, 2018).

Therefore, the internal obstacles to the movement of Ukraine to the EU should be highlighted: first, slow implementation of economic reforms, the absence of noticeable results of domestic socioeconomic transformations; second, the alarming level of corruption and economic crime; third, the lack of consensus regarding the European choice among the population; fourth, a shortage of experienced specialists in European integration, especially among the political elite and public servants of Ukraine (Vidnosyny mizh YeS ta Ukrainoiu: informatsina dovidka); fifth, a huge gap in the levels of economic development of Ukraine and European countries; sixth, a significant difference in living standards; seventh, inconsistency of legal systems (Kvasha, Syniakova, 2019).

Therefore, it should be noted that in the context of social and socio-economic relation globalization, the worldwide economic crisis has led to a reorientation of key values in the world and the European Union countries' search for an acceptable model of economic development to ensure national competitiveness and to empower the national economy of each country for a long-term growth. Consequently, a model of innovation development has become this model, as well as the foundation that determines the economic strength of the country and its prospects on the world market (Lutsykiv, 2010).

Economic disadvantages should be noted, namely: - low level of GDP and per capita income; - loss of competitiveness of certain economic sectors; insufficient level of fulfilling the demand of the domestic market for domestic goods; - uncompetitive products on the foreign market; - the complexity of transition to the European level of prices; - allocating quotas to certain types of goods; - outflow of skilled labour (Todoshchuk; Kvasha, Syniakova, 2019).

Accordingly, economic advantages should be noted: macroeconomic stability; - technological modernization; - free access to the latest technologies, capital, information; - grant of subsidies to agriculture; - attraction of foreign investments and the newest technologies in the Ukrainian economy; - creation of jobs; - common customs tariffs; - anti-dumping policy; protectionism and export control (Todoshchuk; Kvasha, Syniakova, 2019).

Therefore, according to the Strategy for Sustainable Development “Ukraine 2020," Ukraine identifies strategic indicators for implementing the Strategy. Implementation of the Strategy involves achieving key indicators that assess the performance of reforms and programs:

1) In the World Bank's Doing Business rating, Ukraine will be among the first 30 positions;

2) Ukraine's credit rating, that is, rating on liabilities in foreign currency, according to the scale of the rating agency Standard \& Poor's, will not be lower than the investment category $\mathrm{BBB}$;

3) According to the Global Competitiveness Index by the World Economic Forum (WEF), Ukraine will be among the top 40 countries in the world;

4) The gross domestic product (at purchasing power parity) per capita, calculated by the World Bank, will rise up to 16,000 USD;

5 ) According to the World Bank, net income from foreign direct investment in 2015-2020 will be more than 40 billion USD;

6) According to the International Monetary Fund, the maximum ratio of the state budget deficit to the gross domestic product will not exceed 3 percent;

7) According to the International Monetary Fund's estimations, the maximum ratio of the total amount of public debt and the government-guaranteed debt to the gross domestic product will not exceed 60 percent (according to the Maastricht convergence criteria);

8) According to the International Energy Agency, the gross domestic product energy intensity will be 0.2 tons of oil equivalent per 1000 USD of the gross domestic product;

9) The national security and defence budget will be at least 3 percent of the gross domestic product;

10) According to the Stockholm International Peace Research Institute, the number of professional soldiers 
per 1,000 of the population will increase from 2.8 to 5.6 persons;

11) According to Transparency International's corruption perception index, Ukraine will enter the top 50 countries of the world;

12) According to the survey, the level of confidence of experts (attorneys, lawyers) in court will be 70 percent; 13) According to a national survey, the level of public confidence in the law enforcement bodies will be 70 percent;

14) The renewal rate of the personnel of public servants in law enforcement bodies, courts and other state bodies will be up to 70 percent;

15) The limited share of one supplier in total purchases of any energy resource will be no more than 30 percent; 16) According to the World Bank, the average life expectancy of a person will increase by 3 years;

17) The share of local budgets will be at least 65 percent in the consolidated state budget;

18) According to the World Bank, the share of Internet broadband penetration will be 25 subscribers per 100 people;

19) 75 percent of graduates of secondary education establishments will know at least two foreign languages, which will be confirmed by international certificates;

20) Ukraine will join in the International Student Assessment, PISA, and will be included in the top 50 state-members of the Assessment;

21) Ukraine, together with the World Bank, will develop a welfare indicator for citizens, determine its target values, and monitor the changes in this indicator;

22) According to a nationwide poll, 90 percent of Ukrainian citizens will be proud of their state;

23) In the XXXII Summer Olympic Games, Ukraine will win at least 35 medals;

24) According to the Global Talent Competitiveness Index by one of the world's leading business schools INSEAD, Ukraine will enter the top 30 countries in the world;

25) 20 films of Ukrainian production will be released in 2020 (Pro Stratehiiu staloho rozvytku "Ukraina - 2020").

Therefore, it should be underlined that the economic prospect of Ukraine is: - ensuring the development of small and medium-sized businesses; - introduction of EU standards in production; - energy price unification; - transportation within the member countries; - access to the EU market; - increase of domestic commodity producer competitiveness; - advanced training of the labour force; - awarding priory to intellectual investments in high technology; - use of EU regional development funds to accelerate the entry into the higher level of economic development in relation to the countries of the European Union (Todoshchuk; Kvasha, Syniakova, 2019).

Along with the economic prospects of Ukraine, economic threats should be considered: - moving harmful industries to Ukraine; - use of cheap raw material resources of Ukraine; - reduction of the total traditional Ukrainian exports to the EU; - use of cheap labour of Ukraine; - crowding-out of domestic producers from the domestic market; - high European prices (Todoshchuk; Kvasha, Syniakova, 2019).

Moreover, predictive scenarios for the development of the Ukrainian economy and the macroeconomic guidelines to calculate the state budget for the next year should be highlighted.

The first scenario involves reforms and preservation of favourable conditions in world markets. The scenario implies a moderate reaction of the economy to reforms. According to this scenario, GDP growth will be 3\% in $2019,3.8 \%$ in 2020 , and $4.1 \%$ in 2021 . This scenario coincides with the IMF estimates; besides MEDT proposes to form the budget for the next year on the basis of these estimates (Kalachova).

The second scenario involves the implementation of complex reforms, such as land and tax, in the part of enterprise income tax (introduction of a tax on withdrawn capital). The external environment will be favourable. According to this scenario, in 2019, GDP growth will be $4.1 \%$; in 2020, 5\%; in 2021, 5.4\% (Kalachova).

The third scenario is pessimistic. It suggests that negative trends in the external environment will weaken the possibility to implement reforms, first of all, in the financial sector. Slow economic development and the loss of confidence of foreign investors will exacerbate the problem of Ukraine's debt payment. In this scenario, GDP growth will be $1.1 \%$ in 2019 ; in 2020, $1.6 \%$; in $2021,2.1 \%$ (Kalachova).

Thenationaleconomyofanystateisa complexeconomic, social, organizational, scientific, and technological system. It has total economic potential, such as natural resource, industrial, labour, scientific, and technical.

Considering the specificities of the modern period of national development, associated with the occurrence of deep political contradictions, not only those measures, which are connected with the elimination of critical gaps, become extremely important for Ukraine.

More than ever before, it is important to implement reasonable and timely actions, related to ensuring the country's competitive advantages, as well as strengthening control over the processes and phenomena in the context of potential threats, which are not critical at the moment (Shkurupii, 2014).

In such conditions, the goals and objectives of economic development for Ukraine are transformed substantially, while the main problem, that is to create an economy of catching-up modernization, not only remains but gets even more complicated by the exacerbation of socioeconomic issues previously unresolved. In comparison with the average GDP growth rates of neighbouring countries (Poland, Romania, Turkey) for 2011-2014, Ukraine has a twofold lag behind this indicator. According to expert estimates, to catch up with its neighbours by 2030, Ukraine's GDP growth rates should average at $7 \%$ per year during the period. Under the current socioeconomic conditions, this is unlikely (Zvieriakov, 2015). 
Despite all of the above, conditions for the successful reformation of Ukraine's national economy should be created. Therefore, it is necessary: to form a real idea of national development; to have a single transformation program, political will and a team of reformers; to implement rapid (as soon as possible) reform; to liberalize economy (from the old bureaucratic system to transparent market relations) and to have a capable government; to unite and consolidate the entire society; to ensure the equivalence of the Ukrainian economy with the external economic environment; to ensure high social welfare and social protection of the population; to provide the ecological balance of the national economy; to introduce an innovative model for the development of the national economy as soon as possible (Mazaraki, Melnyk, 2011).

\section{Conclusion}

The young Ukrainian State faces extremely complex and significant challenges in the field of the economy. Our progress towards a civilized life depends on their solution to a large extent. Therefore, the realization of the economic program of the newest Ukrainian State should become a concern of every citizen of the country. Accordingly, in order to achieve high social standards, the Ukrainian economy needs some changes. The economic policy of Ukraine should be aimed at the economic growth, an increase of incomes and quality of life as a whole through the transformation of the remuneration system, diversification of the economy due to the creation of attractive investment climate, optimization of the tax system.

Therefore, considering the impact of integration factors on the political, economic, and social spheres of the state, Ukraine's accession to the European Union remains considerably more promising; moreover, the country has already made a lot of efforts towards this and will be improved in order to become a member of the EU in the near future (Kvasha, Syniakova, 2019). Thus, today, as never before, Ukraine's economic development requires a well-balanced and sound macroeconomic policy aimed at further stabilization (Pavlenko, Sevruk, Kobko, 2017).

\section{References:}

Mohilevskyi, L. V., Sevruk, V. G., Pavlenko, S. O. (2017). Psycho-pedagogical training of operating unit workers of national police of Ukraine. Nauka i osvita, 11, 120-132.

Melnykova, V. I. et al. (2011). Natsionalna ekonomika [National economy] (Teaching manual). Kyiv: Center for Educational Literature. (in Ukrainian)

Pavlenko, S. O., Sevruk, V. G., Kobko, Ye. V. (2017). Training police officers in the conditions of reforming the system of education of the Ministry of Internal Affairs of Ukraine in accordance with European Standards. Nauka i osvita, 6, 142-150.

Bahaterenko, O. A. (2013). Problemy ta perspektyvy yevropeyskoi intehratsii Ukrainy [Problems and prospects of European Integration of Ukraine]. Naukovyi visnyk Instytutu mizhnarodnykh vidnosyn NAU. Seriia: ekonomika, pravo, politolohiia, turyzm, 1(1). Retrieved from: http://jrnl.nau.edu.ua/index.php/IMV/article/view/5915 (in Ukrainian) Ruden, V. V. Perspektyvy ta priorytety rozvytku sotsialno-ekonomichnoi systemy Ukrainy [Prospects and priorities of the development of the socio-economic system of Ukraine]. Retrieved from: http://intkonf.org/ruden-vvperspektivi-taprioriteti-rozvitku-sotsialno-ekonomichnoyi-sistemi-ukrayini/ (in Ukrainian)

Yunin, O., Sevruk, V., Pavlenko, S. (2018). Priorities of economic development of Ukraine in the context of European integration. Baltic Journal of Economic Studies, 4(3), 358-365. doi: 10.30525/2256-0742/2018-4-3-358-365

Vidnosyny mizh YeS ta Ukrainoiu: informatsiina dovidka [EU-Ukraine Relations: Information Note]. (March 6, 2018). Retrieved from: https://eeas.europa.eu/headquarters/headquartersHomepage/29685/node/29685_uk(in Ukrainian) Kvasha, O. S., Syniakova, A. V. (2019). Ukraina ta YeS: problemy ta perspektyvy intehratsii v suchasnykh umovakh [Ukraine and the EU: Problems and perspectives of integration in modern conditions]. Naukovyi visnyk Uzhhorodskoho natsionalnoho universytetu, 23(1), 112-117. (in Ukrainian)

Lutsykiv, I. V. (2010). Innovatsiina diialnist v Ukraini: realii sohodennia ta perspektyvy rozvytku [Innovation activity in Ukraine: Realities of the present and prospects of development]. Innovatsiina ekonomika, 8, 22-26. (in Ukrainian) Todoshchuk, A. V. Ukraina $\mathrm{v}$ intehratsiinykh protsesakh: ryzyky ta perevahy [Ukraine in integration processes: risks and advantages]. Retrieved from: http://molodyvcheny.in.ua/files/journal/2017/5/168.pdf (in Ukrainian)

Pro Stratehiiu staloho rozvytku "Ukraina - 2020" [On the Strategy of Sustainable Development "Ukraine 2020"]. Retrieved from: http://zakon.rada.gov.ua/laws/show/5/2015 (in Ukrainian)

Kalachova, H. Kabmin prorakhuvav stsenarii rozvytku ekonomiky na 2019-2021 roky [The Cabinet of Ministers has calculated the scenarios of economic development for 2019-2021]. Retrieved from: https://www.epravda.com.ua/ news/2018/07/11/638606/ (in Ukrainian)

Shkurupii, O. V. (2014). Chynnyky dynamiky ekonomiky Ukrainy ta natsionalnoi konkurentospromozhnosti [Dynamics factors of Ukraine's economy and national competitiveness]. Problemy ekonomiky, 2, 89-94. (in Ukrainian) Zvieriakov, M. I. (2015). Pro zminu modeli ekonomichnoho rozvytku [On changing of economic development model]. Ekonomika Ukrainy, 6(643), 41-49. (in Ukrainian)

Mazaraki, A., Melnyk, T. (2011). Suchasni tendentsii ta chynnyky rozvytku zovnishnoi torhivli Ukrainy [Modern trends and factors in the development of foreign trade of Ukraine]. Visnyk Kyivskoho natsionalnoho torhovelnoekonomichnoho universytetu, 2, 5-14. (in Ukrainian) 